\title{
THE CARDIAC OUTPUT AND OXYGEN CONSUMPTION OF NINE SURGICAL PATIENTS BEFORE AND AFTER OPERATION ${ }^{1}$
}

\author{
BY J. C. SNYDER 2 \\ (From the Surgical Laboratories of the Harvard Medical School at the Massachusetts General \\ Hospital, Boston)
}

(Received for publication April 1, 1938)

The effects of anesthesia and operation on the circulation and metabolic rate of man have not been accurately determined. A few studies of cardiac output and oxygen consumption have been reported in relation to surgical procedures, but the evidence is incomplete and inconclusive. Polano (1), using Broemser's method (2), has interpreted his data as indicating an increase in cardiac output in the immediate postoperative period. Rehn (3), with the same technic, has described a decrease in cardiac output postoperatively in those patients who show signs of shock and collapse. Broemser's method has been criticized on theoretical grounds (4). Altschule and Volk (5), using the ethyl iodide method, have described the changes in cardiac output and oxygen consumption which accompany total thyroidectomy, but they present no data for the immediate postoperative period. Blalock and his coworkers have found that trauma and hemorrhage (acute experiments) depress the cardiac output of dogs (6); that etherization produces an increase in cardiac output and a slight decrease in oxygen consumption; and that under very deep anesthesia the cardiac output returns to normal or is decreased (7).

To determine more definitely the cardiac output and oxygen consumption of human subjects in relation to general surgical procedures, studies have been undertaken on hospital patients before operation, during recovery from anesthesia, and at suitable intervals thereafter.

\section{TECHNICAL DETAILS}

Cardiac output. The ethyl iodide method (8) as modified to permit rapid determinations in unconscious patients was used (9). Before this adaptation could be applied to the study of patients anesthetized with ether, it was necessary to

\footnotetext{
1 Aided by grants from the Josiah Macy, Jr. Foundation and the William F. Milton Fund.

2 Research Fellow in Surgery.
}

determine whether ether vapor affects the accuracy of the chemical determination of ethyl iodide vapor in air samples, or the solubility of ethyl iodide in blood.

\section{A. Ethyl iodide analysis in presence of ether vapor}

The effect of ether vapor on the analysis of ethyl iodide by Cool's method (10) was determined by the following experiments.

A solution of ethyl iodide was prepared by breaking an ampule containing a known weight of redistilled ethyl iodide under the surface of the solute in a partly filled, calibrated liter flask. Fifty per cent ethyl alcohol was found to dissolve the ethyl iodide more rapidly than water and did not affect the results. This solution was pipetted directly into bromine water to compare the accuracy of this method for determining ethyl iodide with Cool's data. Differences between amounts of ethyl iodide expected and amounts obtained were $0.7,0.1$, and 0.1 per cent of the amount present. Double-ended glass sampling tubes, 500 cc. capacity, were charged with ether vapor, 6 to 8 volumes per cent. The solution of ethyl iodide was pipetted into these tubes which were subjected to Cool's procedure. The discrepancy between amounts expected and obtained was 0.6 and 0.4 per cent in two experiments. These differences are of the same order of magnitude as those described by Cool. Additional experiments conducted with titration bottles (see (9), Section II) and known concentrations of ethyl iodide vapor in the presence of ether gave similar results. Ether vapor was therefore considered to have no appreciable effect on the analysis of small amounts of ethyl iodide by the iodate method. (The presence of ether vapor causes a return of the blue color a few minutes after a titration has been completed, so that uniformity of procedure in titrating samples is essential after potassium iodide has been added.) 


\section{B. Distribution coefficient}

There is no reason to expect ether to change the solubility of ethyl iodide in blood. Nevertheless, it was considered advisable to determine the distribution coefficient for the blood of etherized patients since the physiological adjustments which accompany anesthesia and hemorrhage might have a significant effect. Preliminary experiments suggested that it was impossible to estimate distribution coefficients on etherized, preserved blood. Pressure of work prevented making this estimation immediately in the postoperative period on the patients subjected to the other studies. Therefore, blood samples from etherized patients not in the study group were analyzed in duplicate as soon as possible after being taken. The following method was used.

A small room kept at 36 to $38^{\circ} \mathrm{C}$. was equipped with a Van Slyke apparatus, the chamber of which was used as a tonometer. Five cubic centimeters of blood were admitted to the dry chamber followed by $45 \mathrm{cc}$. of gas prepared by adding ethyl iodide to the patient's expired air collected in an anesthesia bag at the time of the venipuncture. The chamber was shaken vigorously for 3 or 4 minutes. Its contents were brought to atmospheric pressure by opening the top stopcock briefly. The chamber was shaken again for 15 minutes. A $50 \mathrm{cc}$. syringe was attached to the side arm of the Van Slyke chamber and the air was slowly admitted to the syringe with as little change in pressure as possible. Another $50 \mathrm{cc}$. syringe was attached and received 6 portions of room air shaken under reduced pressure with the blood in the chamber. Reagents were added to the two syringes and the contents washed into Erlenmeyer flasks for the remaining procedures of the chemical analysis.

Results comparable to Cool, Gamble, and Starr's data (11) were obtained on normal blood treated as above in duplicate, but without ether; 6.99, $6.92,6.94,6.42$, for a red count of 5.5 million. When ether vapor was present, however, the values of a duplicate estimation were more divergent. The average of 6 experiments in duplicate with etherized blood analyzed within an hour of withdrawal was 6.37 for an average red count of 4.6 million, a value which agrees well with the average, 6.44 , for a similar red count, obtained on
15 normal bloods by Cool, Gamble, and Starr. The deviation of duplicates from their mean, 0.91, and the standard deviation about the regression line, 0.74 , are higher than the corresponding figures, 0.36, and 0.41, in Cool, Gamble, and Starr's series. However, it seems probable that etherization does not alter the distribution coefficient except by changing the red count. The data on cardiac output obtained on etherized patients are therefore calculated on the basis of the distribution coefficient as established by the red count or the oxygen capacity of the patient's blood at the time of the determinations.

Blood gases. The usual manometric Van Slyke-Neill technic was employed for routine blood gas analysis (12). For etherized blood, Shaw and Downing's method was used (13). (In some instances the Hempel pipette was replaced with a capillary U-tube blown to the side arm of the Van Slyke chamber.) Blood was collected in an oiled syringe, stored over mercury with dry heparin as anticoagulent, and analyzed in duplicate except as noted in the Appendix to Table I at the end of the paper.

Arterial oxygen saturation. If the arterial oxygen saturation of a patient is reduced during the period of recovery from anesthesia, the ethyl iodide technic cannot be applied for the study of cardiac output unless it is shown that equilibrium as regards ethyl iodide exists between simultaneous samples of alveolar air and arterial blood. Data secured during recovery from anesthesia on the patient (Case 2) whose arterial oxygen saturation was below 91 per cent are indicated in the table but are not employed in the comparison of results of cardiac output. Data for two patients are included although no estimations of arterial oxygen saturation were done, since normal values were obtained for every patient on whose blood duplicate determinations were available.

Oxygen consumption was determined by the analysis of expired air drawn from a mixing bottle $(14$, p. 562$)$; for samples containing ether vapor, a sulphuric acid absorber was used (15).

Blood loss at operation was estimated by a modification of Gatch and Little's method (16).

\section{CLINICAL DETAILS}

The patients were selected from the general surgical wards. They had no cardiovascular dis- 
ease and, with one exception (Case 2), presented no abnormality other than the local lesion. There were 4 patients operated upon for carcinoma of the breast ; 1 for tumor of the pancreas ; 2 patients had perineorrhaphy, suspension of the uterus and appendectomy; 1 had only perineorrhaphy; 2 had gastroenterostomy. Of these patients, one was anemic and required a preoperative transfusion (Case 2) ; two were considered to be emotionally unstable to a degree distinctly exceeding the normal (Cases 7 and 8); and one patient (Case 6), not studied preoperatively, went into shock during operation for which he received two transfusions. Postoperative studies were made before and after a third transfusion, although at the time of the determinations the signs of shock were absent.

Studies of cardiac output and oxygen consumption under basal conditions were made on one or more occasions before operation. Routine preoperative medication was employed; the dosage and time of administration are described in the Appendix to Table I. All patients had gas-oxygen-ether anesthesia except Case 5, who was operated upon under local anesthesia only. Postoperative studies were made as soon as possible after the dressing had been applied to the wound. The etherized patients were unconscious at the time of the determinations which were conducted with one or two variations from the procedures described in (9). An assistant was delegated to keep the lips of the patient firmly shut around the rubber mouthpiece throughout the tests. In some instances a metal airway passing back of the patient's tongue was fitted directly to the mouthpiece. The $R$ period (see (9), Section I-C) was altered. Instead of a liter of air, the $\mathrm{R}$ bag contained only slightly more than the tidal volume of the patient, so that the bag would be emptied with each breath. The $\mathrm{R}$ period was terminated by having an assistant abruptly exert firm pressure on the sides of the patient's thorax during an expiration in order to push as much air as possible into the bag. Subsequent studies were undertaken the morning following operation, again in 3 and 4 days, and at discharge, unless complications intervened. Postoperative medication in relation to the studies is cited in the Appendix to Table I. An oral temperature of $101^{\circ} \mathrm{F}$. or higher, local wound infection, or evidence of infection elsewhere, served in all instances to interrupt or to terminate the observations. Intravenous fluids, as required by routine postoperative care, were administered after the studies of cardiac output and oxygen consumption of the period of recovery from anesthesia had been completed. Three patients (Cases 8, 9, and 10) were given constant intravenous fluids for several days postoperatively for the purpose of another study. In no instances were estimations performed when they might conflict with the patient's well-being.

Blood gases were determined at the times noted in the table and appendix. Blood pressure was taken either during or immediately after the determinations of cardiac output. The capillary red cell count or the venous oxygen capacity of each patient was determined once preoperatively and on the occasion of most estimations of postoperative cardiac output for use in obtaining the distribution coefficient from the data of Cool, Gamble, and Starr (11). Plasma volume studies were conducted on several of the cases immediately before and after operation by Dr. J. D. Stewart. His data appear in another communication (17).

\section{RESULTS}

The diagnoses, and the results of determinations of cardiac output, oxygen consumption, blood pressure, pulse, respirations, temperature, body weight, and venous oxygen capacity (or red count), are presented in Table I. Other pertinent clinical data together with the time and duration of operation, the medication and fluids administered, are contained in the Appendix at the end of the paper.

Figure 1 is a graph showing per cent change in cardiac output plotted against time for the nine patients who had ether anesthesia. The average of the preoperative data for each patient is used to compute the per cent changes, with two exceptions: (a) One patient (Case 8) who had duplicate determinations, on the morning of operation, was apprehensive and the average of the determinations was unduly high. This value was not employed to calculate per cent change. Instead, the basal level which the cardiac output reached in the determinations most remote from the operation was employed. (The cardiac output regularly returned to normal within a few days post- 
TABLE I

Original data and diagnosis of cases

\begin{tabular}{|c|c|c|c|c|c|c|c|c|c|c|c|c|}
\hline$\underset{\text { ber }}{\text { Cace }}$ & Date & Condition & Hour & $\begin{array}{l}\text { Car- } \\
\text { diso } \\
\text { out- } \\
\text { putt }\end{array}$ & $\begin{array}{l}\text { Pulse } \\
\text { rate }\end{array}$ & $\begin{array}{l}\text { Reo- } \\
\text { pira- } \\
\text { tions }\end{array}$ & $\begin{array}{l}\text { Blood } \\
\text { pres: } \\
\text { sure }\end{array}$ & $\begin{array}{c}\text { Oxy- } \\
\text {-gen } \\
\text { oon- } \\
\text { sumedt }\end{array}$ & $\begin{array}{l}\text { Body } \\
\text { weight }\end{array}$ & $\begin{array}{l}\text { Body } \\
\text { tem- } \\
\text { pera- } \\
\text { turet }\end{array}$ & $\begin{array}{l}\text { Venous } \\
\text { oxygen } \\
\text { capac- } \\
\text { ity }\end{array}$ & $\begin{array}{l}\text { Diagnosia; } \\
\text { Type of operation; } \\
\text { Remarks }\end{array}$ \\
\hline 1. & $\begin{array}{c}1987 \\
\\
\text { January } 9 \\
\text { January } 11 \\
\text { January } 12 \\
\text { January } 12 \\
\text { January } 13 \\
\text { January } 22\end{array}$ & $\begin{array}{l}\text { Basal } \\
\text { Basal } \\
\text { Preoperative basal } \\
\text { Postoperative anesthetised } \\
\text { Postoperative 1st day } \\
\text { Postoperative 10th day } \\
8 \text { hours postprandial }\end{array}$ & $\begin{array}{l}\text { 9:15 a.m. } \\
\text { 9:50 a.m. } \\
\text { 9:40 a.m. } \\
\text { 3:50 p.m. } \\
\text { 9:25 a.m. } \\
\text { 2:50 p.m. }\end{array}$ & $\mid \begin{array}{c}\text { liters } \\
\text { por } \\
\text { min- } \\
\text { ute } \\
5.1 \\
4.8 \\
5.0 \\
8.0 \\
5.5\end{array}$ & $\begin{array}{c}\text { per } \\
\text { min- } \\
\text { ute } \\
56 \\
60 \\
64 \\
76 \\
76 \\
64\end{array}$ & $\begin{array}{c}\text { per } \\
\text { min- } \\
\text { ute } \\
14 \\
14 \\
14 \\
17 \\
16 \\
12\end{array}$ & $\begin{array}{c}m, \\
H 0 \\
150-80 \\
130-80 \\
120-80\end{array}$ & $\begin{array}{c}c c . \\
\text { per } \\
\text { minute } \\
191 \\
172 \\
185 \\
165 \\
196 \\
199\end{array}$ & kom. & $\begin{array}{l}\bullet r . \\
97.6 \\
98.2 \\
97.6 \\
97.0 \mathrm{r} \\
99.0 \mathrm{r} \\
97.8\end{array}$ & $\begin{array}{c}\text { oolumes } \\
\text { per } \\
\text { cent }\end{array}$ & $\begin{array}{l}\text { Carcinoma, left breast. Radial mas- } \\
\text { tectomy }\end{array}$ \\
\hline 2. & $\begin{array}{l}\text { January } 19 \\
\text { January } 21 \\
\text { January } 22\end{array}$ & $\begin{array}{l}\text { Basal } \\
\text { Postoperative anesthetised } \\
\text { Postoperative 1st day }\end{array}$ & $\begin{array}{l}\text { 9:00 a.m. } \\
\text { 4:30 p.m. } \\
\text { 9:45 a.m. }\end{array}$ & $\begin{array}{l}6.1 \\
5.5 \\
3.5\end{array}$ & $\begin{array}{r}92 \\
124 \\
112\end{array}$ & $\begin{array}{l}11 \\
19 \\
16\end{array}$ & $\begin{array}{r}130-70 \\
80-50 \\
100-70\end{array}$ & $\begin{array}{l}128 \\
225 \\
248\end{array}$ & 66.9 & $\begin{array}{c}98.0 \\
100.0 \mathrm{r} \\
100.4 \mathrm{r}\end{array}$ & $\begin{array}{l}8.8 \\
8.5 \\
8.1\end{array}$ & $\begin{array}{l}\text { Carcinoma of stomach. Subtotal gas } \\
\text { tric recection. Posterior Polys ans- } \\
\text { stomodis. Death Jan. 23, bilateral } \\
\text { bronchopneumonia }\end{array}$ \\
\hline 8. & $\begin{array}{l}\text { January } 28 \\
\text { January } 29 \\
\text { January } 29 \\
\text { January } 30 \\
\text { February 3 } \\
\text { February } 9\end{array}$ & $\begin{array}{l}\text { Basal } \\
\text { Preoperative basal } \\
\text { Postoperative anesthetised } \\
\text { Postoperative 1st day } \\
\text { Postoperative 4th day } \\
\text { Postoperative 11th day }\end{array}$ & $\begin{array}{l}\text { 9:15 a.m. } \\
\text { 9:25 a.m. } \\
\text { 3:45 p.m. } \\
\text { 9:30 a.m. } \\
\text { 8:50 a.m. } \\
\text { 9:20 a.m. }\end{array}$ & $\begin{array}{l}3.5 \\
3.1 \\
2.1 \\
1.9 \\
2.8 \\
3.8\end{array}$ & $\begin{array}{r}80 \\
94 \\
130 \\
128 \\
88 \\
80\end{array}$ & $\begin{array}{l}16 \\
16 \\
20 \\
16 \\
14 \\
15\end{array}$ & $\begin{array}{l}140-70 \\
136-80 \\
100-62 \\
100-60\end{array}$ & $\begin{array}{l}222 \\
201 \\
180 \\
223 \\
229 \\
187\end{array}$ & $\begin{array}{l}61.5 \\
57.6 \\
58.9\end{array}$ & \begin{tabular}{|c|}
98.0 \\
97.4 \\
$100.4 \mathrm{r}$ \\
100.0 \\
97.8 \\
97.8 \\
\end{tabular} & $\begin{array}{l}4.7 \\
4.9 \\
4.0 \\
3.6\end{array}$ & $\begin{array}{l}\text { Carcinoma of bresst. Radial mas- } \\
\text { tectomy }\end{array}$ \\
\hline 4. & $\begin{array}{l}\text { March } 12 \\
\text { March } 12\end{array}$ & $\begin{array}{l}\text { Preoperative basal } \\
\text { Postoperative anesthetised } \\
\text { Postoperative anesthetired }\end{array}$ & $\begin{array}{l}\text { 8:00 a.m. } \\
\text { 4:05 p.m. } \\
\text { 6:00 p.m. }\end{array}$ & $\begin{array}{l}8.7 \\
1.8 \\
8.9\end{array}$ & $\begin{array}{r}100 \\
100 \\
72\end{array}$ & $\begin{array}{l}24 \\
20 \\
20\end{array}$ & $\begin{array}{r}160-76 \\
85-50 \\
95-55 \\
\end{array}$ & $\begin{array}{l}178 \\
190 \\
\end{array}$ & 61.5 & $\begin{array}{r}98.4 \\
100.0 \mathrm{r} \\
\end{array}$ & $\begin{array}{l}18.5 \\
16.2\end{array}$ & $\begin{array}{l}\text { Carcinoma of breast. Radical mas. } \\
\text { tectomy. Btreptococous hemolyticus } \\
\text { septicemia. Death March 16 }\end{array}$ \\
\hline 5. & $\begin{array}{l}\text { March } 23 \\
\text { March 25 } \\
\text { April } 8 \\
\end{array}$ & $\begin{array}{l}\text { Basal } \\
\text { Postoperative } \\
\text { Postoperative 13th day }\end{array}$ & $\begin{array}{l}\text { 10:00 a.m. } \\
\text { 3:30 p.m. } \\
\text { 9:15 a.m. }\end{array}$ & $\begin{array}{l}2.8 \\
3.8 \\
2.8\end{array}$ & $\begin{array}{r}78 \\
102 \\
74\end{array}$ & $\begin{array}{l}15 \\
25 \\
13\end{array}$ & $\begin{array}{l}138-90 \\
116-78\end{array}$ & $\begin{array}{l}187 \\
199 \\
178 \\
\end{array}$ & $\begin{array}{l}42.2 \\
40.9 \\
\end{array}$ & $\begin{array}{l}98.8 \\
99.4 \\
98.6 \\
\end{array}$ & 16.2 & $\begin{array}{l}\text { Obstructive duodenal ulcer. Posterior } \\
\text { gastroenterostomy. Local anesthesia }\end{array}$ \\
\hline 6. & April 1 & $\begin{array}{l}\text { Postoperative anesthetized } \\
\text { Conscious }\end{array}$ & $\begin{array}{l}\text { 2:45 p.m. } \\
\text { 4:15 p.m. }\end{array}$ & $\begin{array}{l}8.7 \\
8.8\end{array}$ & $\begin{array}{l}140 \\
112\end{array}$ & $\begin{array}{l}32 \\
26\end{array}$ & $70-30$ & $\begin{array}{l}260 \\
262\end{array}$ & 68.2 & $\begin{array}{l}97.2 \\
98.4\end{array}$ & 17.2 & $\begin{array}{l}\text { Duodenal ulcer and retroperitoneal tu- } \\
\text { mor. Resection of tumor and loop of } \\
\text { jejunum. Death, April 5, peritonitis } \\
\text { and bronchopneumonia }\end{array}$ \\
\hline 7. & $\begin{array}{l}\text { April } 9 \\
\text { April 10 } \\
\text { April 10 } \\
\text { April 11 } \\
\text { April 13 } \\
\text { April 23 }\end{array}$ & $\begin{array}{l}\text { Basal } \\
\text { Preoperative basal } \\
\text { Postoperative anesthetired } \\
\text { Postoperative 1st day } \\
\text { Postoperative 3d day } \\
\text { Postoperative 13th day } \\
\end{array}$ & $\begin{array}{c}\text { 10:00 a.m. } \\
\text { 7:55 a.m. } \\
\text { 11:50-12:30 } \\
9: 10 \text { a.m. } \\
\text { 9:05 a.m. } \\
\text { 8:50 a.m. } \\
\end{array}$ & $\begin{array}{l}4.4 \\
3.5 \\
2.4^{\circ} \\
3.0 \\
3.7 \\
3.9 \\
\end{array}$ & $\begin{array}{l}80 \\
80 \\
98 \\
96 \\
85 \\
82 \\
\end{array}$ & $\begin{array}{l}11 \\
15 \\
20 \\
15 \\
15 \\
14 \\
\end{array}$ & $\begin{array}{r}100-60 \\
80-62 \\
100-70 \\
114-78 \\
90-62 \\
\end{array}$ & $\begin{array}{l}221 \\
202 \\
227 \\
232 \\
205 \\
\end{array}$ & 56.6 & $\begin{array}{c}98.6 \\
98.0 \\
100.0 \\
100.7 \mathrm{r} \\
100.2 \mathrm{r} \\
98.6 \\
\end{array}$ & $\begin{array}{l}18.9 \\
20.7 \\
16.8\end{array}$ & $\begin{array}{l}\text { Acuto intraluminal sppendicitis. Ero- } \\
\text { sion of cervix, oystocele, rectocele. } \\
\text { Perinesl repair, suspension of uterus, } \\
\text { sppendectomy }\end{array}$ \\
\hline 8. & $\begin{array}{l}\text { April } 23 \\
\text { April 28 } \\
\text { April 24 } \\
\text { April 28 }\end{array}$ & $\begin{array}{l}\text { Preoperative basal } \\
\text { Postoperative anesthetised } \\
\text { Postoperative 1st day } \\
\text { Postoperative 5th day } \\
\end{array}$ & $\begin{array}{r}10: 30 \text { a.m. } \\
4: 25-4: 50 \\
9: 45 \text { a.m. } \\
8: 40 \text { a.m. }\end{array}$ & $\begin{array}{l}7.1 \\
2.3^{*} \\
3.8 \\
3.5\end{array}$ & $\begin{array}{l}96 \\
80 \\
92 \\
96\end{array}$ & $\begin{array}{l}12 \\
15 \\
15 \\
12\end{array}$ & $\begin{array}{r}86-52 \\
112-64 \\
116-70 \\
\end{array}$ & $\begin{array}{l}211 \\
211 \\
230 \\
218\end{array}$ & $\begin{array}{l}59.6 \\
58.9 \\
62.0\end{array}$ & $\begin{array}{l}98.4 \\
99.0 \\
99.6 \\
99.6\end{array}$ & $\begin{array}{l}17.0 \\
15.7 \\
11.7\end{array}$ & $\begin{array}{l}\text { Carcinoms of right breast. Radical } \\
\text { mastectomy. Constant intravenous } \\
\text { postoperatively }\end{array}$ \\
\hline 9. & $\begin{array}{l}\text { May } 18 \\
\text { May } 19 \\
\text { May } 19 \\
\text { May } 20 \\
\text { May } 24 \\
\text { May } 28 \\
\end{array}$ & $\begin{array}{l}\text { Basal } \\
\text { Preoperative basal } \\
\text { Postoperative anesthetised } \\
\text { Postoperative 1st day } \\
\text { Postoperative 4th day } \\
\text { Postoperative 9th day } \\
\end{array}$ & $\begin{array}{r}\text { 9:30 a.m. } \\
9: 50 \text { a.m. } \\
1: 10-1: 30 \\
10: 00 \text { a.m. } \\
9: 20 \text { a.m. } \\
8: 55 \text { a.m. }\end{array}$ & \begin{tabular}{l|}
3.4 \\
3.9 \\
$2.1^{*}$ \\
3.5 \\
3.4 \\
3.8 \\
\end{tabular} & $\begin{array}{l}66 \\
78 \\
90 \\
96 \\
78 \\
64 \\
\end{array}$ & $\begin{array}{l}18 \\
20 \\
14 \\
16 \\
20 \\
20\end{array}$ & $\begin{array}{l}120-80 \\
100-72 \\
128-80 \\
148-88 \\
114-74 \\
\end{array}$ & $\begin{array}{l}214 \\
168 \\
244 \\
262 \\
204 \\
\end{array}$ & $\begin{array}{l}60.5 \\
60.0 \\
67.2 \\
58.2 \\
\end{array}$ & $\begin{array}{r}98.6 \\
98.4 \\
99.5 \\
99.6 \\
100.0 \\
99.0 \\
\end{array}$ & $\begin{array}{l}16.3 \\
16.8 \\
11.9 \\
13.5 \\
\end{array}$ & $\begin{array}{l}\text { Cystocele, rectocele. Perineal repair, } \\
\text { appendectomy. Constant intravenous } \\
\text { postoperatively }\end{array}$ \\
\hline 10. & $\begin{array}{r}\text { June } 8 \\
\text { June } 8 \\
\text { June } 9 \\
\end{array}$ & $\begin{array}{l}\text { Preoperative bassal } \\
\text { Postoperative snesthetised } \\
\text { Postoperative 1st day }\end{array}$ & $\begin{array}{l}\text { 8:30 a.m. } \\
\text { 2:45-3:00 } \\
\text { 9:40 a.m. }\end{array}$ & $\begin{array}{l}4.8 \\
2.4^{*} \\
4.8 \\
\end{array}$ & $\begin{array}{l}73 \\
95 \\
84 \\
\end{array}$ & $\begin{array}{l}11 \\
16 \\
11 \\
\end{array}$ & $\begin{array}{l}118-80 \\
100-72 \\
108-68 \\
\end{array}$ & $\begin{array}{l}220 \\
232\end{array}$ & $\begin{array}{l}69.8 \\
68.4\end{array}$ & $\begin{array}{l}98.0 \\
98.2 \\
98.0 \\
\end{array}$ & $\begin{array}{l}18.1 \\
15.3\end{array}$ & $\begin{array}{l}\text { Cystocele, rectocele. Perineal repair. } \\
\text { Constant intravenous postoperatively }\end{array}$ \\
\hline 11. & $\begin{array}{l}\text { June } 24 \\
\text { June } 25 \\
\text { June } 25\end{array}$ & $\begin{array}{l}8 \text { hours postprandial } \\
\text { Pre-ther basal } \\
\text { During ether } \\
\text { During ether } \\
\text { During ether } \\
\text { During ether } \\
\text { During ether } \\
\text { Post ether anesthetised } \\
\text { Post ether } \\
\text { Basal next day }\end{array}$ & $\begin{array}{l}\text { 5:00 p.m. } \\
\text { 11:00-12 a.m. } \\
\text { 2:42 p.m. } \\
\text { 2:50 p.m. } \\
\text { 3:00 p.m. } \\
\text { 3:10 p.m. } \\
\text { 3:22 p.m. } \\
\text { 4:10 p.m. } \\
\text { 4:40 p.m. } \\
\text { 9:50 a.m. }\end{array}$ & $\begin{array}{l}4.9 \\
3.9^{*} \\
4.1 \\
6.5 \\
6.4 \\
3.4 \\
3.6 \\
3.9 \\
4.8 \\
4.0\end{array}$ & $\begin{array}{l}65 \\
63 \\
81 \\
92 \\
96 \\
78 \\
82 \\
74 \\
98 \\
76\end{array}$ & $\begin{array}{l}16 \\
13 \\
16 \\
15 \\
12 \\
16 \\
16 \\
13 \\
19 \\
16\end{array}$ & $\begin{array}{l}114-68 \\
150-68 \\
160-60 \\
130-70 \\
135-68 \\
125-70 \\
118-68 \\
120-60\end{array}$ & $\begin{array}{l}248 \\
208 \\
378 \\
\\
332 \\
320 \\
\end{array}$ & 66.5 & 98.2 & $\begin{array}{l}18.4 \\
18.9\end{array}$ & $\begin{array}{l}\text { Normal, healthy, adult male. Ether- } \\
\text { isation, no operation }\end{array}$ \\
\hline
\end{tabular}

† Figures in italics are single estimations; those marked with * are average of triplicate estimations; others are average of duplicate estimations.

$\ddagger$ Body temperature is oral unless marked with letter r-rectal.

Figures in italics are red cells in millions per cu. mm.; others are oxygen capacity.

operatively in the other cases.) (b) For the patient (Case 6) not studied preoperatively who went into shock during the operation, a normal cardiac output for his height and weight is assumed.
The cases operated upon under ether show uniformly a reduction of cardiac output in the period of recovery from anesthesia varying from 32 to 51 per cent of the basal preoperative value, the average being 41.1 per cent. This decrease per- 


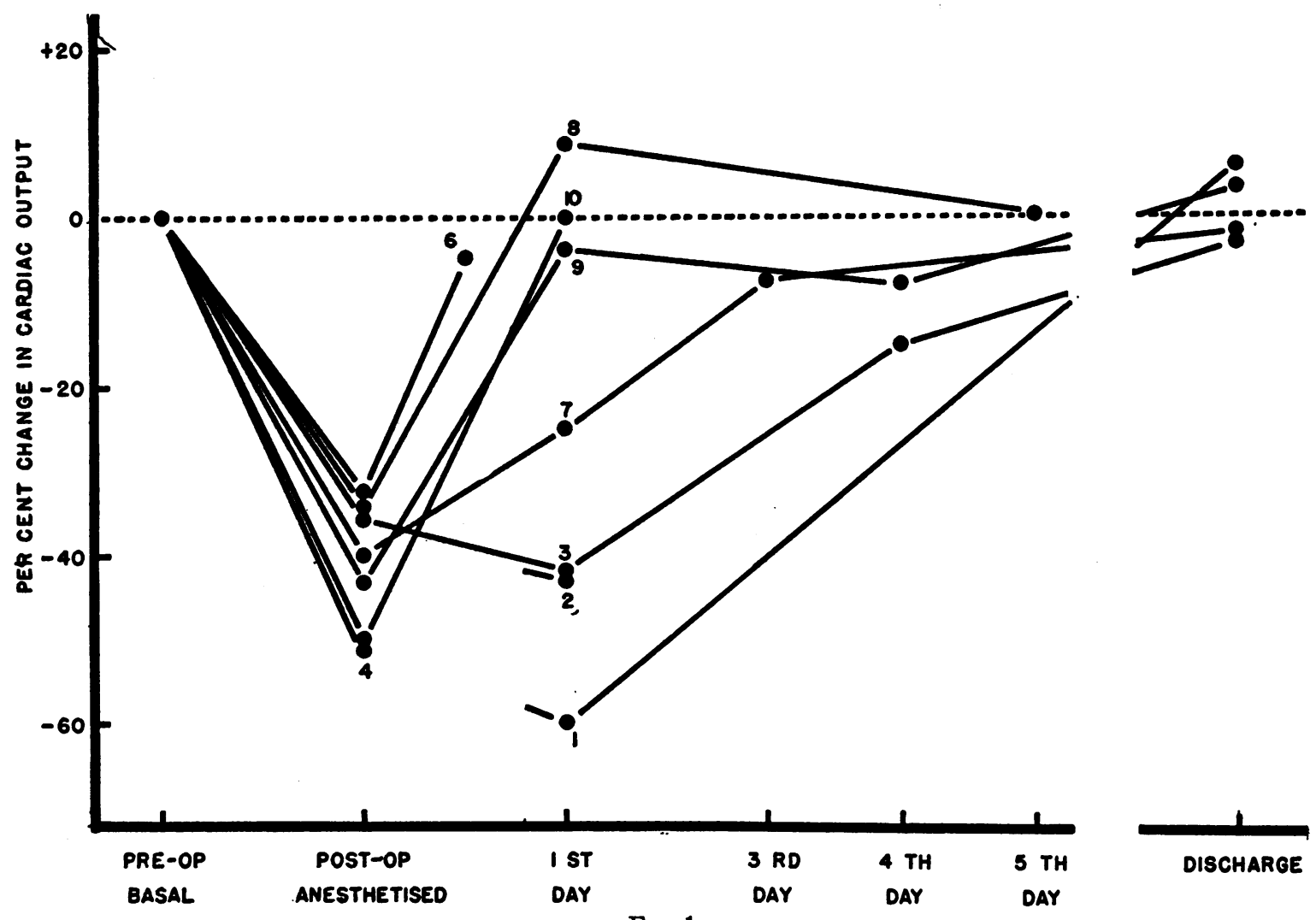

FIG. 1

Per Cent Change in Cardiac Output Plotted Against Time for 9 Patients Who Had Ether Anesthesia

sists in some instances the following day. The three patients (Cases 8, 9, and 10) who received large volumes of intravenous fluid beginning immediately after the conclusion of the first studies of postoperative cardiac output, exhibited a return of cardiac output to a normal level on the morning following operation, a level which was maintained during the succeeding studies. The patient (Case 5) who had local anesthesia furnished the only instance of an elevated cardiac output immediately following operation. The patient (Case 6) who had been in shock during the operation showed after recovery from shock no greater depression of output than the other cases (at the time measurements were made the patient had received two transfusions and was no longer in shock); after the third transfusion his cardiac output was normal for a man of his height and weight. The patients (Cases 7 and 8) who were unduly apprehensive preoperatively showed no appreciable differences from the other patients in the postoperative period.
An attempt was made to determine the cardiac output during etherization as well as during the period of recovery from anesthesia. A volunteer healthy male subject was admitted to the hospital as a patient (Case 11, Table I). He was given routine preoperative medication. Studies of cardiac output and oxygen consumption were made before, during, and after etherization without surgical procedures. The preether medication (pentobarbital) made the subject so drowsy that he fell asleep repeatedly during the preliminary tests, making it difficult to obtain satisfactory basal determinations. Routine anesthesia was employed, gas-oxygen for the induction process followed by ether. When light third-stage anesthesia was attained, the mouthpiece of the ethyl iodide apparatus was fitted to a metal airway passing behind the subject's tongue. Between the spirometer and the sampling tube for inspired air, a pair of etherizing bottles in parallel was inserted. No appreciable resistance to inspiration is offered by such an arrangement regardless of the position of the valves diverting the air stream through the ether bottles. This method was adopted when preliminary tests revealed that within half an hour ether vapor stored in a spirometer (painted with red lead) formed appreciable amounts of aldehydes and peroxides which render ether unfit as an anesthetic agent for humans. The anesthesia was light and quite irregu- 
lar; large fluctuations in pulse rate and blood pressure occurred, and the respiratory minute volume varied more than it would have done had the inspired air been charged with 2 or 3 per cent of carbon dioxide. Five determinations of cardiac output were made at 10 -minute intervals during etherization; the anesthesia was discontinued; and 2 more estimations were made as the subject recovered from the etherization. Studies were made again the following morning. Blood samples totalling approximately $140 \mathrm{cc}$. were withdrawn for the purposes of plasma volume studies and blood gas analysis.

The average of the $\mathbf{5}$ determinations of cardiac output obtained under ether is 10 per cent greater than the average for pre- and postetherization periods. The latter agree closely. There was no depression of cardiac output in this subject as he recovered from anesthesia. The difference in depth of anesthesia between this subject and the patients who were operated upon may explain the difference in the data obtained, but the experiment was so unsatisfactory in a technical sense that no conclusions may be drawn.

The oxygen consumption data (Table I) do not exhibit any consistent change.

The average decrease of arterial blood pressure in the period of recovery from etherization was $31 \mathrm{~mm}$. $\mathrm{Hg}$ systolic and $11 \mathrm{~mm}$. diastolic (Case 11 not included).

\section{DISCUSSION}

The results of such studies of cardiac output as these may be interpreted in the manner described by Starr et al. (18, pp. 800 to 802 ). For the computation of a testing standard deviation, 24 pairs of duplicate estimations made on 9 subjects were available in the present study (see Table I and (9) Table II). The data were obtained entirely from hospital patients under basal conditions, pre- and postoperatively (data obtained within 60 hours after operation and anesthesia are not included in the calculations). The standard deviation is 7.9 per cent, a value which is higher than that for the 65 pairs of duplicates computed by Starr et al., 5.6 per cent. Several factors probably contribute to this difference. The patients in this study had been in the hospital for such a short time that the effect of a new environment must be considered. The impending operations created many problems, for example, financial matters, apprehension of pain, discomfort, serious outcome, and so forth. It is therefore not unreasonable to expect a greater variation in preoperative determinations in this group of patients than in the group studied by Starr et al. More- over, the modification of Starr and Gamble's technic is slightly less accurate for normals (9). Finally, the small size of the series may affect the results. When the value, 7.9 per cent, is applied to the average decrease in cardiac output during the period of recovery from anesthesia, in the manner described by Starr et al., the probability that the difference observed is due to chance is insignificant. The morphine administered preoperatively may contribute somewhat to the depression of cardiac output, but it certainly is only a minor factor in the period of recovery from anesthesia (18).

The changes in oxygen consumption in the period of recovery from ether anesthesia do not parallel the consistent decrease which is found in the cardiac output. The calculated arteriovenous oxygen difference, however, shows a definite and regular increase. It is not possible to estimate from these limited data the relative importance of drugs, etherization, blood loss, and operative trauma, or of changes in oxygen consumption in producing the decrease in cardiac output observed. It is clear, however, that these factors, and probably others also, acting together do depress the circulation in man by a significant amount.

\section{SUMMARY AND CONCLUSIONS}

Data are presented which show the cardiac output and oxygen consumption of nine patients studied before and after surgical operations, performed under ether anesthesia, by a modification of Starr and Gamble's ethyl iodide technic (Table I and Figure 1).

The average cardiac output in the period of recovery from etherization was decreased by 41 per cent of the preoperative level. Return to normal required 1 to 4 days (Figure 1 ).

The patient receiving only local anesthesia had an elevation of cardiac output immediately after the operation (Table I).

Changes in oxygen consumption were occasionally large, but not consistent (Table I).

\section{APPENDIX TO TABLE I}

Case 1. Age 62 , $q$, height $162 \mathrm{~cm}$. Arterial oxygen saturation Jan. 12 at 4:00 p.m., 98 per cent (wet heparin single estimation, under oil). Operation Jan. 12 from $1: 40$ to $3: 10$ p.m. Con- 
scious at $5: 45$ p.m. Medication: Jan. 11, phenobarbital grains 2 at 9 p.m. Jan. 12, pantopon ${ }^{3}$ grains $1 / 3$ and atropine sulphate grains $1 / 100$ at $12: 30$ p.m. Pantopon grains $1 / 3$ at $7: 40$ p.m. Jan. 13, pantopon grains $1 / 3$ at 2:00 a.m., 8:30 a.m., $7: 10$ p.m. Intravenous fluid 1500 cc. 5 per cent glucose in 0.85 per cent saline from 11 a.m. to 1 p.m.

Case 2. Age 57, $q$, height $137 \mathrm{~cm}$. Blood loss 0.2 liter. Arterial saturation Jan. 21 at 5:00 p.m. 83 per cent (wet heparin single determination, under oil). Operation Jan. 21, from $1: 50$ to 4:15 p.m. Conscious at 7:30 p.m. Medication: Jan. 20, transfusion $500 \mathrm{cc}$. citrated blood. Phenobarbital grains 2 at 9:00 p.m. Jan. 21, pantopon grains $1 / 3$ at 9:00 a.m. Pantopon grains $1 / 3$ and atropine sulphate grains $1 / 100$ at $12: 45$ p.m. ; 1000 cc. 10 per cent glucose in 0.85 per cent saline $12: 00$ to $1: 00$ p.m.; 1500 cc. 5 per cent dextrose in 0.85 per cent saline 8:00 to $11: 00$ p.m. Pantopon grains $1 / 3$ at $8: 15$ p.m., $11: 15$ p.m. Jan. 22, pantopon grains $1 / 3$ at $3: 05$ a.m., $6: 15$ a.m., 9:00 a.m.

Case 3. Age 49, $\$$, height $173.5 \mathrm{~cm}$., arterial oxygen saturation Jan. 29, at 4:00 p.m., 91 per cent (single determination, wet heparin, under oil). Operation Jan. 29 from $1: 40$ to $3: 20$ p.m. Conscious at 5:00 p.m. Medication: Jan. 27, phenobarbital grains 1.5 at 9:00 p.m. Jan. 28, phenobarbital grains 2 at 9:10 p.m. Jan. 29, pantopon grains $1 / 3$ and atropine sulphate grains $1 / 100$ at 12:50 p.m. Morphine sulphate grains $1 / 6$ at $11: 25$ p.m. Intravenous fluid $1500 \mathrm{cc}$. of 5 per cent glucose in 0.85 per cent saline, from 5:00 to 8:00 p.m. Jan. 30, morphine sulphate grains $1 / 6$ at $3: 25$ a.m., $8: 45$ a.m., $11: 50$ a.m., $11: 50$ p.m.

Case 4. Age 62, $q$, height $165 \mathrm{~cm}$. Blood loss 0.4 liter. Arterial saturation Mar. 12 at 5:10 p.m., 93 per cent (wet heparin, single estimation, under oil). Operation Mar. 12 from 2:10 to 3:45 p.m. Conscious at 7:15 p.m. Medication: Mar. 11, phenobarbital grains 1.5 at 9:00 p.m. Mar. 12, pentobarbital grains 1.5 at $12: 00$ noon, morphine sulphate grains $1 / 6$ and atropine sulphate grains $1 / 100$ at $1: 30$ p.m., morphine sulphate grains $1 / 6$ at $8: 35$ p.m.

3 "Pantopon" = pantopium hydrochloricum, HoffmanRoche, grains $1 / 3$ contains the alkaloids in grains $11 / 3$ opium.
Case 5. Age 55, $\sigma^{\lambda}$, height $159 \mathrm{~cm}$. Local anesthesia. Operation Mar. 25 from 1:20 to 2:41 p.m. Medication: Mar. 22, morphine sulphate grains $1 / 6$ at 3:10 p.m. Atropine sulphate grains $1 / 100$. Cevitamic acid 0.1 gram intravenously. Mar. 24, codein sulphate grains 1 at 3:10 a.m. Phenobarbital grains 2 at $7: 45$ p.m. Mar. 25, phenobarbital grains 2 at 12:00 noon. Morphine sulphate grains $1 / 6$ at $12: 10$ p.m.

Case 6. Age 56, ${ }^{\star}$, height $178 \mathrm{~cm}$. Operation Apr. 1 from 10:20 a.m. to 2:05 p.m. Conscious at 3:40 p.m. Medication: Mar. 31, barbital grains 10 at 9 p.m. Apr. 1, 1000 cc. 5 per cent dextrose in 0.85 per cent saline from $8: 30$ to $10: 00$ a.m. Pentobarbital grains 1.5 at 8:00 a.m. Morphine sulphate grains $1 / 6$ and atropine sulphate grains $1 / 100$ at $9: 15$ a.m. Transfusion 600 cc. citrated blood 12:20 p.m. Transfusion 600 cc. citrated blood 1:20 p.m. Transfusion 600 cc. citrated blood 3:00 p.m. Morphine sulphate grains 1/6 at $3: 45$ p.m.

Case 7. Age 30, $q$, height $159 \mathrm{~cm}$. Blood loss 0.3 liter. Arterial oxygen saturation Apr. 10, at 12 noon, 92 per cent. Operation Apr. 10 from $9: 30$ to $11: 25$ a.m. Conscious at $1: 00$ p.m. Medication: Apr. 9, barbital grains 10 at $8: 40$ p.m., Apr. 10, pentobarbital grains 1.5 at $7: 00$ a.m., morphine sulphate grains $1 / 6$, atropine sulphate grains $1 / 100,8: 20$ a.m., morphine sulphate grains $1 / 6$ at $1: 20,4: 00$, and $7: 00$ p.m. $1800 \mathrm{cc}$. 5 per cent dextrose in 0.85 per cent saline from 2:30 to $4: 30$ p.m. Apr. 11,1000 cc. 5 per cent dextrose in 0.85 per cent saline from 10:00 to 12:00 a.m. Morphine sulphate grains $1 / 6$ at $1: 00$ a.m., 8:10 a.m., 2:45 p.m., 8:50 p.m., Apr. 12, morphine sulphate grains $1 / 6$ at $2: 45$ a.m., $10: 35$ a.m., $5: 30$ p.m., 10:45 p.m. Apr. 13, morphine sulphate grains $1 / 6$ at $11: 15$ p.m.

Case 8. Age 38, $q$, height $157 \mathrm{~cm}$., blood loss 0.5 liter, arterial oxygen saturation Apr. 23 at 4:50 p.m., 95 per cent. Operation Apr. 23 from $2: 08$ to $4: 05$ p.m. Conscious at $6: 45$ p.m. Medication: Apr. 22, pentobarbital grains 1.5 at $10: 20$ p.m., Apr. 23, pentobarbital grains 1.5 at 12 noon, morphine sulphate grains $1 / 6$, atropine sulphate grains $1 / 100$ at $1: 10$ p.m., morphine sulphate grains $1 / 6$ at $6: 50$ p.m. Apr. 24, morphine sulphate grains $1 / 6$ at 2:10 a.m., 9:15 a.m., $12: 55$ p.m., 6:00 p.m., 9:15 p.m. Apr. 25, morphine sulphate grains $1 / 6$ at $4: 15$ a.m., $11: 10$ a.m., $3: 25$ a.m., $8: 40$ 
p.m. Apr. 26, morphine sulphate grains $1 / 6$ at $12: 35$ a.m., $4: 00$ a.m., 8:20 a.m., $4: 20$ p.m., 8:40 p.m. Apr. 27, morphine sulphate grains $1 / 6$ at 2:25 a.m., 9:20 a.m., $1: 50$ p.m., 6:05 p.m., 9:25 p.m. Apr. 28, morphine sulphate grains $1 / 6$ at 12:55 a.m., $4: 30$ a.m., $7: 30$ a.m., 10:30 a.m. Intravenous fluids: From Apr. 23 at 6 p.m. to Apr. 24 at 7:00 a.m., 3.5 liters 0.85 per cent saline. From Apr. 24 to Apr. 28, 7 to 9 liters a day.

Case 9. Age 35, $\uparrow$, height $156 \mathrm{~cm}$., blood loss 0.2 liter, arterial oxygen saturation May 19, at $1: 47$ p.m., 95 per cent. Operation May 19 from $11: 35$ a.m. to $12: 50$ p.m. Conscious at 2:00 p.m. Medication: May 18, pentobarbital grains 1.5 at 8:00 p.m. May 19, pentobarbital grains 1.5 at $7: 30$ a.m., pantopon grains $1 / 3$ and atropine sulphate grains $1 / 100$ at $10: 50$ a.m. Morphine sulphate grains $1 / 6$ at 2:10 p.m., $5: 20$ p.m., $10: 45$ p.m. May 20, morphine sulphate grains $1 / 6$ at $1: 45$ a.m., $4: 45$ a.m., $7: 40$ a.m., $2: 15$ p.m., $7: 45$ p.m., $10: 45$ p.m. May 21, morphine sulphate grains $1 / 6$ at 6:30 a.m., 6:45 p.m. May 22, morphine sulphate grains $1 / 6$ at $7: 25$ a.m., 3:55 p.m., 8:50 p.m. May 23, morphine sulphate grains $1 / 6$ at 10:35 a.m., 9:00 p.m. May 24, morphine sulphate grains $1 / 6$ at 10:23 a.m., $12: 20$ p.m. May 25, morphine sulphate grains $1 / 6$ at 12:05 a.m. May 26, pentobarbital grains 1.5 at 9:20 p.m. May 27, pentobarbital grains 1.5 at 9:10 p.m. May 28, chloral hydrate grains 20 at 2:00 a.m. Intravenous fluids: May 19 from 3:00 p.m. to May 20 at 7:00 a.m., 3.1 liters 0.85 per cent saline. Four to 6 liters a day from May 20 to May 24.

Case 10. Age 43, + , height $169 \mathrm{~cm}$., blood loss 0.5 liter, arterial oxygen saturation June 8 at $3: 00$ p.m., 95 per cent. Operation June 8, from 12:05 p.m. to 2:30 p.m. Conscious at $3: 10$ p.m. Medication: June 7, pentobarbital grains 1.5 at 9:00 p.m. June 8, pentobarbital grains 1.5 at $7: 15$ a.m. Pantopon grains $1 / 3$ and atropine sulphate grains $1 / 100$ at $11: 15$ a.m. Morphine sulphate grains $1 / 6$ at 3:15 p.m. June 9, morphine sulphate grains $1 / 6$ at 8:00 a.m. Intravenous fluids: 1.9 liters saline, from 4:00 p.m. June 8 to 9:00 a.m. June 9 .

Case 11. Age 22, $\delta$, height $177 \mathrm{~cm}$., arterial oxygen saturation June 25 at $4: 20$ p.m., 95 per cent. Etherization June 25 from $2: 15$ to $3: 30$ p.m. Conscious at 4:30 p.m. Medication: June 24, pentobarbital grains 1.5 at $11: 00$ p.m. June
25 , pentobarbital grains 1.5 at $7: 45$ a.m. Morphine sulphate grains $1 / 6$ and atropine sulphate grains $1 / 100$ at $1: 45$ p.m. Barbital grains 5 at 9:00 p.m. June 26, barbital grains 5 at $2: 40$ a.m.

The advice and suggestions given by Dr. Isaac Starr, and the technical assistance of Miss Margaret Rourke and Miss Virginia Dewey are gratefully acknowledged.

\section{BIBLIOGRAPHY}

1. Polano, Hans, Experimentelle Untersuchungen über das Verhalten des Minutenvolumens des menschlichen Herzens bei Äthernarkose, Lumbalanästhesie und nach operativen Eingriffen. Deutsche Ztschr. f. Chir., 1933, 239, 505.

2. Broemser, P., and Ranke, O. F., Ueber die Messung des Schlagvolumens des Herzens auf unblutigem Weg. Ztschr. f. Biol., 1930, 90, 467.

3. Rehn, E., Herzkraft und Kreislauf bei mittelbarer und unmittelbarer chirurgischer Belastung. Klin. Wchnschr., 1936, 15, 1625.

4. Bazett, H. C., Cotton, F. S., Laplace, L. B., and Scott, J. C., The calculation of cardiac output and effective peripheral resistance from blood pressure measurements with an appendix on the size of the aorta in man. Am. J. Physiol., 1935, 113, 312.

5. Altschule, M. D., and Volk, M. C., Therapeutic effect of total ablation of normal thyroid on congestive failure and angina pectoris. XVIII. The cardiac output following total thyroidectomy in patients with and without congestive heart failure, with a comparison of results obtained with the acetylene and ethyl iodide methods. Arch. Int. Med., 1936, 58, 32.

6. Johnson, G. S., and Blalock, A., Experimental shock. XII. A study of the effects of hemorrhage, of trauma to muscles, of trauma to the intestines, of burns, and of histamine on the cardiac output and on blood pressure of dogs. Arch. Surg., 1931, 23, 855.

7. Blalock, A., Cardiac output in the dog during ether anesthesia. I. The effect of ether anesthesia. on the cardiac output. Arch. Surg., 1927, 14, 732.

8. Starr, I., Jr., and Gamble, C. J., An improved method for the determination of cardiac output in man by means of ethyl iodide. Am. J. Physiol., 1928, 87, 450.

9. Snyder, J. C., The determination of the cardiac output in man at brief intervals by a modification of the ethyl iodide method.' J. Clin. Invest., 1938, 17, 563.

10. Cool, R. D., Determination of small amounts of ethyl iodide. J. Biol. Chem., 1932, 97, 47.

11. Cool, R. D., Gamble, C. J., and Starr, I., Jr., The solubility of ethyl iodide in human blood and its 
correlation with the erythrocyte count. J. Biol. Chem., 1934, 105, 97.

12. Van Slyke, D. D., and Neill, J. M., The determination of gases in blood and other solutions by vacuum extraction and manometric measurement. I. J. Biol. Chem., 1924, 61, 523.

13. Shaw, J. L., and Downing, V., The determination of oxygen in blood in the presence of ether by a modification of the Van Slyke-Neill technique. J. Biol. Chem., 1935, 109, 405.

14. Starr, I., Jr., Donal, J. S., Margolies, A., Shaw, R., Collins, L. H., and Gamble, C. J., Studies of the heart and circulation in disease; estimations of basal cardiac output, metabolism, heart size, and blood pressure in 235 subjects. J. Clin. Invest., $1934,13,561$.
15. Snyder, J. C., A note on the use of the Haldane apparatus for the analysis of gases containing ether vapor. J. Biol. Chem., 1937, 122, 21.

16. Gatch, W. D., and Little, W. D., Amount of blood lost during some of the more common operations. Preliminary report. J. A. M. A., 1924, 83, 1075.

17. Stewart, John D., and Rourke, G. M., Changes in blood and interstitial fluid resulting from surgical operation and ether anesthesia. J. Clin. Invest., 1938, 17, 413.

18. Starr, I., Gamble, C. J., Margolies, A., Donal, J. S., Jr., Joseph, N., and Eagle, E., A clinical study of the action of 10 commonly used drugs on cardiac output, work, and size; on respiration, on metabolic rate, and on the electrocardiogram. J. Clin. Invest., 1937, 16, 799. 